Dhanashri P. Miskin, MD

Spyridon G. Chalkias, MD

Xin Dang, PhD

Evelyn Bord, BS

Stephanie Batson, BS

Igor J. Koralnik, MD

Correspondence to

Dr. Koralnik:

ikoralni@bidmc.harvard.edu

\title{
Interleukin-7 treatment of PML in a patient with idiopathic lymphocytopenia
} OPEN

\section{ABSTRACT}

Objective: To describe the compassionate use of interleukin-7 (IL-7) for treatment of progressive multifocal leukoencephalopathy (PML) in the setting of idiopathic CD8+ greater than CD4+ lymphocytopenia.

Methods: A 66-year-old HIV-seronegative man presented with progressive language dysfunction. MRI showed hyperintense lesions in the left hemispheric white matter with mild contrast enhancement. A brain biopsy performed 4 months after symptom onset established the diagnosis of PML. The patient had profound lymphocytopenia with absolute lymphocyte count (ALC) at 168 cells/ $\mu \mathrm{L}, 87 \mathrm{CD} 4+\mathrm{T}$ cells $/ \mu \mathrm{L}$, and $7 \mathrm{CD} 8+\mathrm{T}$ cells/ $\mu \mathrm{L}$. There was no evidence of hematologic malignancy or rheumatologic disease.

Results: The patient received 3 intramuscular injections of IL-7 at a dose of $10 \mu \mathrm{g} / \mathrm{kg}$ per week with no adverse effects. ALC peaked at 595 cells/ $\mu \mathrm{L}, \mathrm{CD} 4+\mathrm{T}$ cells at $301 \mathrm{cells} / \mu \mathrm{L}$, and CD8+ T cells at 34 cells $/ \mu \mathrm{L} 3$ weeks after completion of treatment. His lesions on MRI stabilized and neurologic examination mildly improved. JCV-specific T-cell responses measured by intracellular cytokine staining were not altered after treatment with IL-7 but there was a marked increase in regulatory $T$ cells.

Conclusion: This case further supports the investigational use of IL-7 in patients who develop PML in the setting of ICL.

Classification of evidence: This study provides Class IV evidence that for patients with ICL and PML, IL-7 improves PML-related-outcomes. The study is rated Class IV because it is a case report. Neurol Neuroimmunol Neuroinflamm 2016;3:e213; doi: 10.1212/NXI.0000000000000213

\section{GLOSSARY}

IL-7 = interleukin-7; IRIS = immune reconstitution inflammatory syndrome; JCV = JC polyomavirus; Lip1/Cr $=$ lipid $1 /$ creatine; MRS = magnetic resonance spectroscopy; $\mathbf{N I H S S}=\mathrm{NIH}$ Stroke Scale; $\mathbf{P M L}=$ progressive multifocal leukoencephalopathy; $\mathbf{T R e g}=$ regulatory T cell.

Progressive multifocal leukoencephalopathy (PML), caused by the JC polyomavirus (JCV), is a demyelinating disorder for which there is no cure. ${ }^{1}$ Upon review of the literature, 12 previous cases of PML in the setting of idiopathic CD4+ lymphocytopenia (ICL) have been reported. ${ }^{2}$ ICL is diagnosed when absolute CD4+ T-cell counts are less than 300 cells $/ \mu \mathrm{L}$ on more than one occasion in the absence of other causes of immunocompromised state. ${ }^{3}$ Several medications have been utilized for treatment of PML in patients with ICL, but none has proven efficacious. ${ }^{4}$ However, recovery of anti-JCV T-cell responses correlates with PML survival. ${ }^{5}$ Interleukin-7 (IL-7) is a multifunctional cytokine that is essential for T-cell proliferation, modulation of peripheral T-cell subsets, and enhancement of T-cell functionality, including virus-specific immunity. ${ }^{6}$ Recently, IL-7 has been used in Europe for treatment of PML in the setting of ICL and secondary lymphocytopenia with normal CD8+ T-cell counts. ${ }^{7-9} \mathrm{We}$

\footnotetext{
From the Division of Neuro-Immunology, Department of Neurology, Center for Virology and Vaccine Research, Department of Medicine, Beth
Israel Deaconess Medical Center, Harvard Medical School, Boston, MA.

From the Division of Neuro-Immunology, Department of Neurology, Center for Virology and Vaccine Research, Department of Medicine, Beth
Israel Deaconess Medical Center, Harvard Medical School, Boston, MA. Funding information and disclosures are provided at the end of the article. Go to Neurology.org/nn for full disclosure forms. The Article Processing
Charge was paid by the authors. Funding information and disclosures are provided at the end of the article. Go to Neurology.org/nn for full disclosure forms. The Article Processing
Charge was paid by the authors.

This is an open access article distributed under the terms of the Creative Commons Attribution-NonCommercial-NoDerivatives License 4.0 (CC BY-NC-ND), which permits downloading and sharing the work provided it is properly cited. The work cannot be changed in any way or used commercially.
} 

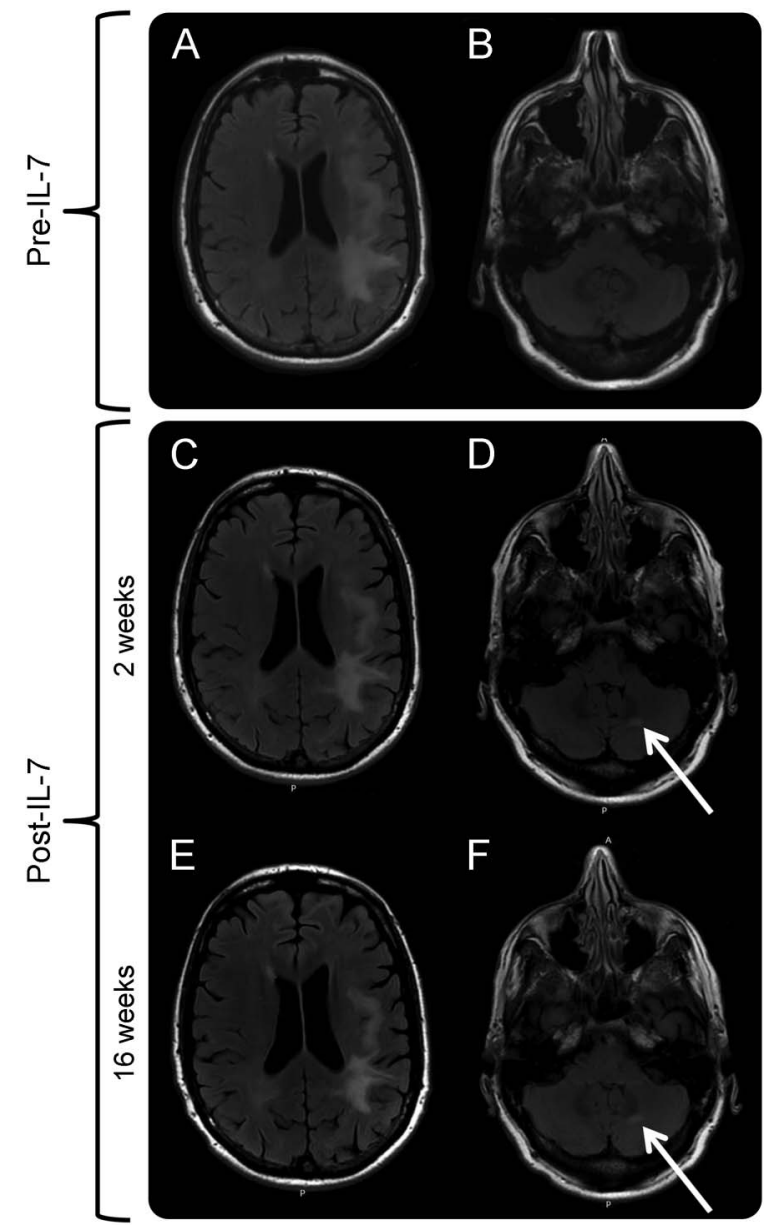

Axial fluid-attenuated inversion recovery images from (A, B) pre-IL-7 and (C, D) 2 weeks post-IL$7 \mathrm{MRI}$ of the brain demonstrate stable left hemispheric subcortical progressive multifocal leukoencephalopathy (PML) lesions, but a new, small, asymptomatic left cerebellar lesion (white arrow), $(E, F)$ which remains unchanged on the most recent MRI performed 16 weeks after IL-7 therapy.

report the case of a patient with lymphocytopenia affecting $\mathrm{CD} 8+$ more than $\mathrm{CD} 4+\mathrm{T}$ cells as well as B cells who developed PML and was treated with IL-7. We studied radiologic markers of disease evolution using magnetic resonance spectroscopy (MRS) and perfusion MRI and monitored his immune response to JCV using intracellular cytokine staining.

CASE REPORT A 66-year-old man with a history of hypertension and hypercholesterolemia began to notice subtle problems with language. One month later, an outpatient brain MRI was interpreted as subacute left temporo-parietal stroke, leading to his hospitalization at our institution. Complete blood count (CBC) on admission showed 6,700 leukocytes with $5.9 \%$ lymphocytes corresponding to an absolute lymphocyte count (ALC) of

395 cells $/ \mu \mathrm{L}$. He was discharged on antiplatelet and statin therapies, but his symptoms progressed over the next 2 months as he developed worsening wordfinding difficulties, paraphasic errors, and trouble reading and writing. A repeat brain MRI was interpreted as increased edema in the left hemisphere with possible cortical enhancement. He was again hospitalized and CSF examination showed 3 leukocytes, 1,045 erythrocytes, protein $36 \mathrm{mg} / \mathrm{dL}$, and glucose $77 \mathrm{mg} / \mathrm{dL}$. Herpes simplex virus 1 and 2 DNA was not detected via PCR. MRS revealed an elevated choline peak in the left parietal white matter suggestive of malignancy. $\mathrm{CBC}$ on admission showed 4,700 leukocytes with 7\% lymphocytes corresponding to an ALC of 329 cells $/ \mu \mathrm{L}$.

The patient underwent elective stereotactic brain biopsy of the left temporo-parietal brain lesion 1 month later, for presumptive diagnosis of glioma. Histopathologic examination revealed marked reactive gliosis, scattered bizarre astrocytes with enlarged nuclei, and numerous SV40-positive nuclear inclusions, consistent with the diagnosis of PML. There was infiltration by $\mathrm{CD} 3+\mathrm{T}$ and $\mathrm{CD} 20+\mathrm{B}$ lymphocytes, as well as numerous $\mathrm{CD} 68+$ macrophages. $\mathrm{He}$ was subsequently evaluated in our Neuroinfectious Diseases Clinic, at which time his neurologic examination showed a mixed expressive greater than receptive aphasia (NIH Stroke Scale [NIHSS] score $=1$ ). Brain MRI 1 month after biopsy showed mildly enhancing left hemispheric PML lesions and MRS revealed a lipid $1 /$ creatine (Lip1/Cr) ratio $>1.5$ in the left temporo-parietal lesion indicating a $79 \%$ likelihood of immune reconstitution inflammatory syndrome (IRIS). ${ }^{10}$ Arterial spin labeling MRI showed no evidence of hyperperfusion around the PML lesions, consistent with a favorable outcome. ${ }^{11}$ Serologic tests were negative for HIV-1, HIV-2, hepatitis, antinuclear antibodies, dsDNA, ribosomal $\mathrm{P}$ antibody, and Sjögren antibodies. The erythrocyte sedimentation rate, angiotensin-converting enzyme, rheumatoid factor, and complement levels were within normal limits. Immunoglobulin (Ig) studies were normal (IgG total 1,331 mg/dL, IgA $196 \mathrm{mg} /$ $\mathrm{dL}$, and $\mathrm{IgM} 166 \mathrm{mg} / \mathrm{dL}$ ). Initial T-cell subsets revealed profound lymphocytopenia (ALC 168 cells/ $\mu \mathrm{L}, \mathrm{CD} 4+$ count 87 cells $/ \mu \mathrm{L}, \mathrm{CD} 8+$ count 7 cells $/ \mu \mathrm{L}, \mathrm{CD} 4 / \mathrm{CD} 8$ ratio 12.4 , and $\mathrm{CD} 19+/$ $\mathrm{CD} 20+$ counts $4-8$ cells $/ \mu \mathrm{L})$. Based upon the absence of history of recurrent infections, inflammatory or autoimmune disorders, malignancy, recent surgery, or bone marrow suppressing medications, the most likely diagnosis was believed to be idiopathic lymphocytopenia. Retrospective review of past records indicated that this patient already had a low ALC 8 years $(590$ cells $/ \mu \mathrm{L})$ and 4 years $(310$ cells/ $\mu \mathrm{L})$ prior to the onset of PML symptoms. JCV DNA 
in CSF was not detected by PCR, but quantitative PCR in DNA extracted from paraffin sections of brain tissue showed 5.2 million JCV copies/slide. This confirmed the diagnosis of PML in the setting of idiopathic lymphocytopenia involving CD8+ more than CD4+ T cells.

METHODS Standard protocol approvals, registrations, and patient consents. We obtained an emergency investigational new drug approval from the Food and Drug Administration for the compassionate use of IL-7 (CYT107, RevImmune, Paris, France). Single-patient use institutional review board approval was obtained from the Beth Israel Deaconess Medical Center (BIDMC) Committee on Clinical Investigations. A Materials Transfer Agreement between RevImmune and BIDMC was negotiated. Written informed consent was obtained from the patient. CYT107 was dispensed by the BIDMC research pharmacy and administered in the BIDMC Infusion Center. We used the NIHSS to assess for changes in neurologic status.

RESULTS A single cycle of IL-7 was administered intramuscularly once weekly for 3 consecutive weeks at a dose of $10 \mu \mathrm{g} / \mathrm{kg}$ with no adverse effects. The patient's neurologic examination showed a stable moderate mixed aphasia (NIHSS $=1$ ) with no new neurologic deficits compared to a pre-IL-7 examination. Brain MRI 2 weeks post IL-7 showed less conspicuous but persistently enhancing left hemispheric PML lesions, and a new, small, enhancing left cerebellar lesion (figure 1). MRS was unchanged in the left temporo-parietal region, and the new left cerebellar enhancing lesion had a Lip1/ $\mathrm{Cr}$ ratio $\leq 1.5 .{ }^{10} \mathrm{CSF}$ JCV DNA was again undetectable by PCR 3 weeks post IL-7. From the first measurement of T-cell subsets 2 months pre-IL7 to repeat T-cell subsets 3 weeks post IL-7, there was an increase in ALC from 168 to 595 cells/ $\mu \mathrm{L}$, CD4+ $\mathrm{T}$ cells from 87 to 301 cells $/ \mu \mathrm{L}$, and CD8 $+\mathrm{T}$ cells from 7 to 34 cells $/ \mu \mathrm{L}$ (figure 2). Twenty-nine weeks after IL-7 therapy, there was a decline in ALC to 242 cells $/ \mu \mathrm{L}, \mathrm{CD} 4+\mathrm{T}$ cells to 87 cells/ $\mu \mathrm{L}$, and CD $8+$ T cells to 4 cells/ $\mu \mathrm{L}$, back to pre-IL-7 baseline levels. Over 6 months, the B cells remained stably low, ranging from 4 to 41 cells/ $\mu \mathrm{L}$. The leukocyte count fluctuated significantly throughout IL-7 treatment, but always remained in the normal range (4.5-9.4 $\mathrm{K} / \mu \mathrm{L})$. JCV-specific CD4+ and CD8+ T-cell responses were measured by intracellular cytokine staining 1 week pre-IL-7, and they were unaltered 1 week post-IL-7 treatment. Interestingly, IL-7 induced a 10 -fold increase in the overall percentage of regulatory $\mathrm{T}$ cells $\left(\mathrm{T}_{\text {Regs }}\right)$ (figure 3 ). While recent studies have shown that IL-2 is the main factor driving the development of $\mathrm{T}_{\text {Regs }}$, IL-7 can also mediate intrathymic $\mathrm{T}_{\mathrm{Reg}}$ development. ${ }^{6}$ On the

Figure 2 Evolution of blood cell counts during interleukin (IL)-7 therapy

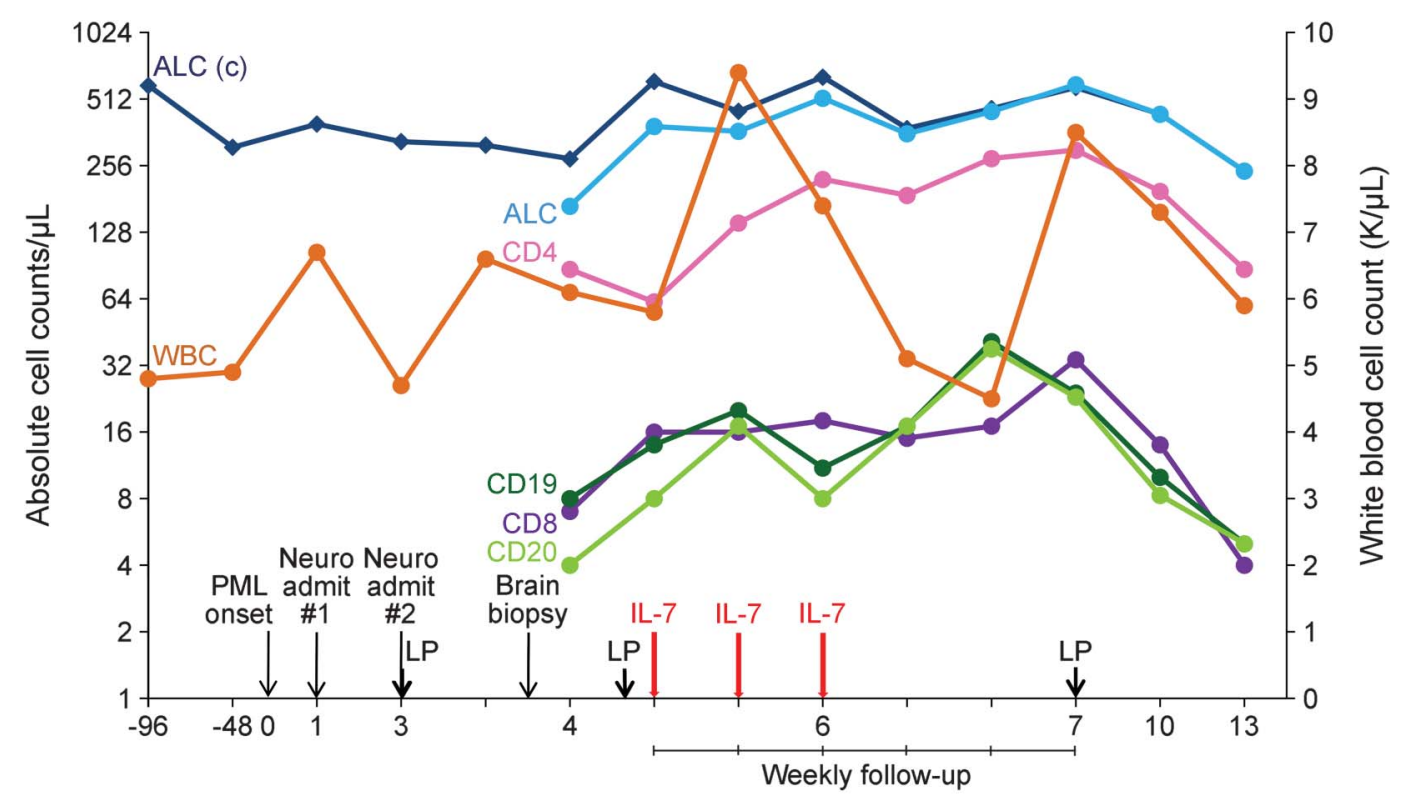

Time (months)

The leukocyte count is displayed using the linear $y$-axis on the right side, while the absolute lymphocyte counts, T-cell, and Bcell subsets are displayed on the logarithmic $y$-axis on the left side. The $x$-axis displays time in months. Time of onset of progressive multifocal leukoencephalopathy (PML) symptoms (PML onset), neurology admissions (Neuro admit 1 and 2), lumbar puncture (LP), and IL-7 injections are indicated by downward arrows along the $x$-axis. ALC (c) = calculated absolute lymphocyte counts based on total leukocyte counts and lymphocyte percentage; ALC = absolute lymphocyte count measured by the clinical laboratory; CD4 $=$ CD4 + T cells; $C D 8=C D 8+T$ cells; CD19 = CD19 + B cells; CD20 = CD20 + B cells; WBC $=$ leukocyte count. 
Figure $3 \quad$ Evolution of JC virus (JCV)-specific $T$-cell responses during interleukin (IL)-7 therapy

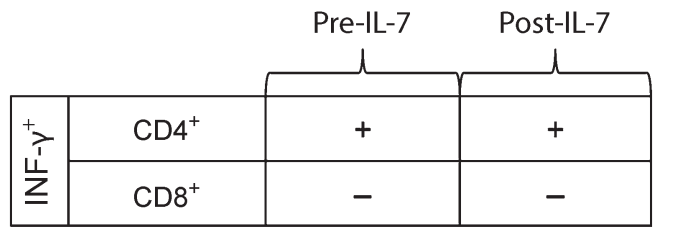

\begin{tabular}{|c|c|c|c|}
\hline$\stackrel{\circ}{\circ}$ & $\mathrm{CD}^{+}$ & - & - \\
\cline { 2 - 4 }$=$ & $\mathrm{CD}^{+}$ & + & + \\
\hline
\end{tabular}

\begin{tabular}{|l|l|l|}
\hline$\% \mathrm{CD}^{+} \mathrm{T}_{\text {regs }}$ & 0.30 & 3.43 \\
\hline
\end{tabular}

JCV-specific CD4+ and CD8 $+\mathrm{T}$ cells expressing interferon- $\gamma$ (INF- $\gamma$ ) and IL-10 remained stable 1 week after treatment with IL-7, but there was a 10-fold increase in the overall percentage of regulatory $T$ cells $\left(T_{\text {Regs }}=\right.$ CD4+CD25+CD127low).

patient's most recent MRI 16 weeks after treatment, the PML lesions remained unchanged except for the disappearance of contrast enhancement. There was also a decrease in the $\mathrm{Lip} 1 / \mathrm{Cr}$ ratio $<1.5$, indicating resolution of IRIS. The patient was started on trimethoprim/sulfamethoxazole for prevention of other opportunistic infections. On his 7-month follow-up post IL-7 administration, 13 months after onset of PML, his neurologic examination showed mild improvement in speed and fluency of speech (NIHSS $=1$ ).

DISCUSSION Effective treatments for PML do not exist, and standard therapies to increase $\mathrm{CD} 4+$ and $\mathrm{CD} 8+\mathrm{T}$ cells or improve immune function in ICL are not commercially available. One of the key drivers of T-cell homeostasis and function is IL-7, and preliminary data indicate that this cytokine may augment virus-specific immune responses, which could provide clinical benefit for immunosuppressed individuals, including those with ICL. ${ }^{6}$ Due to the often fatal outcome of PML, our patient was treated with intramuscular injections of IL-7 with the aim to restore overall immune function. Uniquely, our patient had multiple lymphocytopenias with low $\mathrm{CD} 8+\mathrm{T}$ cells, CD4 $+\mathrm{T}$ cells, and $\mathrm{B}$ cells. The effects of IL-7 were selective with regard to T-cell subsets as the $\mathrm{CD} 4+\mathrm{T}$-cell population expanded to a greater extent than CD8 $+\mathrm{T}$ cells. This is relevant since $\mathrm{CD} 8+\mathrm{T}$ cells are thought to be most important in containing JC virus. As expected, there was no effect on B-cell counts. Of note, treatment with IL7 was well-tolerated, with no IRIS during 7 months of follow-up. CD4 + T-cell counts remained elevated for approximately 3 months after treatment with IL-7.
Given that the half-life of IL-7 is 7-23 hours, our results suggest that the biological effects of IL-7 on blood cell counts continue after serum cytokine levels return to baseline, usually 72 hours after injection. ${ }^{6}$ Thus, in the present case, investigational use of IL-7 led to rapid increase in overall CD4 $+\mathrm{T}$-cell counts and was associated with clinical benefit. Since the patient remains alive more than 1 year from PML onset, he is considered a PML survivor, and is expected to have a favorable long-term clinical outcome. ${ }^{12}$ Further prospective studies of IL-7 for treatment of PML in patients with ICL are warranted.

\section{AUTHOR CONTRIBUTIONS}

Dr. Miskin was involved in conceptualization of the study, acquisition of the study drug, analysis and interpretation of the data, and drafting of the manuscript. Dr. Chalkias was involved in analysis and interpretation of the data and critical revision of the manuscript. Dr. Dang was involved in conduction of the experiments. E. Bord was involved in conduction of the experiments. S. Batson was involved in conduction of the experiments. Dr. Koralnik was involved in conceptualization of the study, analysis and interpretation of the data, critical revision, and finalization of the manuscript.

\section{ACKNOWLEDGMENT}

The authors thank the patient, his family, and the drug manufacturer for giving permission to publish this case.

\section{STUDY FUNDING}

Supported by NIH grants R01NS 047029 and 074995 . The study drug (CYT107) was provided free of charge by the drug manufacturer (RevImmune).

\section{DISCLOSURE}

D.P. Miskin reports no disclosures. S.G. Chalkias received research support from NIH. X. Dang, E. Bord, and S. Batson report no disclosures. I. J. Koralnik served on the scientific advisory board for Hoffman La Roche, GlaxoSmithKline, Merck Serono, Johnson \& Johnson, and Medimmune; serves on the editorial board for Journal of NeuroVirology and Annals of Neurology; received publishing royalties from UpToDate; has consulted for Bristol Meyers Squibb, Ono Pharmaceuticals, Merck Serono, Hoffman La Roche, GlaxoSmithKline, Perseid Therapeutics, Vertex Pharmaceutical, and Johnson \& Johnson; and received research support from Biogen Idec, NIH, and National Multiple Sclerosis Society. Go to Neurology.org/nn for full disclosure forms.

Received November 2, 2015. Accepted in final form December 23, 2015.

\section{REFERENCES}

1. Gheuens S, Wuthrich C, Koralnik IJ. Progressive multifocal leukoencephalopathy: why gray and white matter. Annu Rev Pathol 2013;8:189-215.

2. Delgado-Alvarado M, Sedano MJ, GonzalezQuintanilla V, de Lucas EM, Polo JM, Berciano J. Progressive multifocal leukoencephalopathy and idiopathic CD4 lymphocytopenia. J Neurol Sci 2013;327:75-79.

3. Zonios DI, Falloon J, Bennett JE, et al. Idiopathic CD4+ lymphocytopenia: natural history and prognostic factors. Blood 2008;112:287-294.

4. Patel A, Patel J, Ikwuagwu J. Treatment of progressive multifocal leukoencephalopathy and idiopathic CD4+ lymphocytopenia. J Antimicrob Chemother 2010;65: 2489-2492.

5. Gheuens S, Bord E, Kesari S, et al. Role of CD4+ and $\mathrm{CD} 8+\mathrm{T}$-cell responses against JC virus in the outcome of 
patients with progressive multifocal leukoencephalopathy (PML) and PML with immune reconstitution inflammatory syndrome. J Virol 2011;85:7256-7263.

6. Mackall CL, Fry TJ, Gress RE. Harnessing the biology of IL-7 for therapeutic application. Nat Rev Immunol 2011; 11:330-342.

7. Alstadhaug KB, Croughs T, Henriksen S, et al. Treatment of progressive multifocal leukoencephalopathy with interleukin 7. JAMA Neurol 2014;71:1030-1035.

8. Sospedra M, Schippling S, Yousef S, et al. Treating progressive multifocal leukoencephalopathy with interleukin 7 and vaccination with JC virus capsid protein VP1. Clin Infect Dis 2014;59:1588-1592.

9. Gasnault J, de Goer de Herve MG, Michot JM, et al. Efficacy of recombinant human interleukin 7 in a patient with severe lymphopenia-related progressive multifocal leukoencephalopathy. Open Forum Infect Dis 2014;1: ofu074.

10. Gheuens S, Ngo L, Wang X, Alsop DC, Lenkinski RE, Koralnik IJ. Metabolic profile of PML lesions in patients with and without IRIS: an observational study. Neurology 2012;79:1041-1048.

11. Khoury MN, Gheuens S, Ngo L, Wang X, Alsop DC, Koralnik IJ. Hyperperfusion in progressive multifocal leukoencephalopathy is associated with disease progression and absence of immune reconstitution inflammatory syndrome. Brain 2013;136:3441-3450.

12. Marzocchetti A, Tompkins T, Clifford DB, et al. Determinants of survival in progressive multifocal leukoencephalopathy. Neurology 2009;73:1551-1558. 


\section{Neurology \\ Neuroimmunology \& Neuroinflammation}

Interleukin-7 treatment of PML in a patient with idiopathic lymphocytopenia

Dhanashri P. Miskin, Spyridon G. Chalkias, Xin Dang, et al.

Neurol Neuroimmunol Neuroinflamm 2016;3;

DOI 10.1212/NXI.0000000000000213

This information is current as of March 21, 2016

Updated Information \&

Services

References

Permissions \& Licensing

Reprints including high resolution figures, can be found at:

http://nn.neurology.org/content/3/2/e213.full.html

This article cites 12 articles, 2 of which you can access for free at: http://nn.neurology.org/content/3/2/e213.full.html\#\#ref-list-1

Information about reproducing this article in parts (figures,tables) or in its entirety can be found online at:

http://nn.neurology.org/misc/about.xhtml\#permissions

Information about ordering reprints can be found online: http://nn.neurology.org/misc/addir.xhtml\#reprintsus

Neurol Neuroimmunol Neuroinflamm is an official journal of the American Academy of Neurology.

Published since April 2014, it is an open-access, online-only, continuous publication journal. Copyright $@$ 2016 American Academy of Neurology. All rights reserved. Online ISSN: 2332-7812.

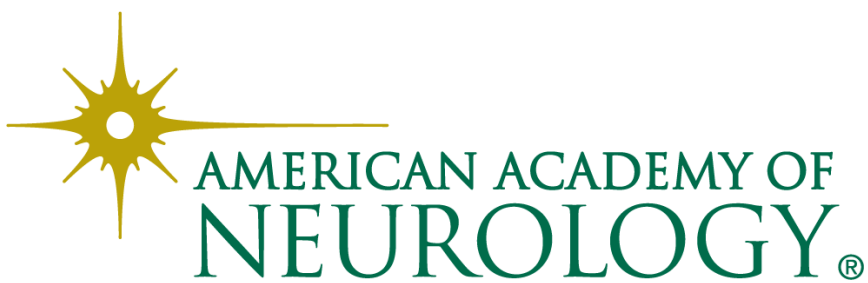

